Yılmaz, Toktaş

Amasya University, Turkey

\title{
SPATIAL ANALYSIS OF RELATIONSHIP BETWEEN COVID-19 CASES AND GLOBALISATION IN EUROPE
}

With the globalisation process, economic, social and political structures have become more and more intertwined. Due to the current Covid-19 pandemic, it has been observed that epidemics such as Covid-19 are globalising and that they turn into pandemics on a global scale. In this study, it is suggested that, along with Covid-19's distinctive abilities such as spreading rapidly, the fact that the world has become more mobile and integrated due to globalisation is considered to have an impact on the pandemic; thus, the effect of globalisation on Covid-19 cases in European countries was investigated through spatial analysis methods. The results of Moran's I test carried out on Covid-19 cases in European countries suggest that there is positive autocorrelation. According to the LISA analysis results, it was found that the UK, the Netherlands, France, and Belgium not only have a higher number of Covid-19 cases, but also have been affected by the countries with a number of cases above the European mean. According to the results of Spatial Error Model designed to examine the effect of globalisation, it was found that globalisation had a slight but positive effect on Covid-19 cases in Europe.

Keywords: spatial analyses, Covid-19, Europe, globalisation

JEL codes: I1, P1, F6

\section{Introduction}

The Covid-19 outbreak began in China's Wuhan in late December 2019, and epidemiological researchers suspect it to have originated from the South China Seafood Market in Wuhan. The Chinese government notified the World Health Organisation (WHO) about the outbreak on the 3rd of January and in relation with the outbreak a novel type of coronavirus was identified on the 7th of January. The WHO named this new virus COVID-19 ${ }^{1}$. Upon its first identification in China on January 3rd, the virus affected more than 210 countries in less than 3 months' time. Among several essential measures taken against the virus, social distancing and isolation at home are considered the most important. Some governments have even gone so far as to impose lockdowns/curfews in certain periods. These lockdowns have had a major impact on the form and type of world trade. It is interesting to take into consideration the changes in human behaviour in the long run. On the other hand, the lockdowns have caused a decrease in energy and material consumption.

Measures taken against Covid-19 may have an impact on trade. For instance, in many countries, transportation operations are threatened. Perishable goods such as

${ }^{1}$ Coronavirus Pneumonia Emergency Response Epidemiology Novel, "The epidemiological characteristics of an outbreak of 2019 novel coronavirus diseases (COVID-19) in China," Zhonghua liu xing bing xue za zhi= Zhonghua liuxingbingxue zazhi 41, no. 2 (2020). 
fresh fruits and vegetables, fish and fish products are facing the risk of getting spoilt due to the strict measures imposed on transportation operations. Factories producing food products may slow down their production process due to the effort they put in keeping up with the health standards ${ }^{2}$. Along with its impact on people's lives in terms of health, Covid-19 is causing a dramatic change in employment due to the economic recession and panic it has created in countries' economies. Covid-19's impact on employment will be varying from sector to sector; some sectors will encounter a surge in demand, others a surge in supply. While sectors related to healthcare and social services have seen an increased demand in employment, airline pilots and hotel staff have faced low supply shocks and strong demand shocks. Manual workers such as stonemasons and roofers, for whom it is impossible to work from home, are threatened by a strong supply shock. Professions such as cooks, waiters, and dishwashers are threatened not only by unfavourable demand shocks as the demand for restaurants go down, but also by a supply shock as they cannot work from home ${ }^{3}$. Moreover, measures restricting people's free movement which affect the likes of seasonal workers may have an impact on food production and hence may affect market prices globally ${ }^{4}$. Although Covid-19 is essentially a disease affecting human health, it is also a situation with socio-economic impacts on countries' economies, lifestyles, and consumption habits. The impact it has had on strong economies in the world is important ${ }^{5}$.

Globalisation can be defined as the global integration of societies and economies by transcending the nation-state's borders with the help of international trade, capital, ideas and human movement. Just as it shapes the modern world, globalisation also causes social, cultural and environmental problems ${ }^{6}$. The twentieth century positively affected the lives of those who lived in Europe. Compared to a family living in the 1990s, a family living in Europe in the 2000s had better access to more commodities, services, food, accommodation, summer holidays, travel, and healthcare services. Rapid globalisation has ended the political division in Europe; thus, in the 1990s, Europe was transformed into a homogenous landscape with market economies and multi-party democracies. With the European Union project, Europe increased tariffs and restrictions in order to preserve the domestic market. They tried to protect the common domestic market; however, as a result of the global world economy, European countries had to compete with countries that had much lower income and social expenses. The leading European economies are those industrialised countries with welfare state understanding. In this light, the welfare state understanding in European countries does not seem to completely agree with the neo-liberal understanding ${ }^{7}$.

Recently, the Covid-19 pandemic tops the whole world's agenda. In this period, people are recommended to stay at home, and in some countries, it is made an obligation

\footnotetext{
2 "Novel Coronavirus (COVID-19)," 2020, http://www.fao.org/2019-ncov/q-and-a/impact-on-food-andagriculture/en/.

${ }^{3}$ R Maria del Rio-Chanona et al., "Supply and demand shocks in the COVID-19 pandemic: An industry and occupation perspective," arXiv preprint arXiv:2004.06759 (2020).

${ }^{4}$ FAO, "Novel Coronavirus (COVID-19)."

${ }^{5}$ Richard Baldwin and Beatrice Weeder di Maura, Economics in the Time of Covid-19 (CEPR Press, 2020).

${ }^{6}$ Leon Brittan, Globalisation Vs. Sovereignty? The European Response: The 1997 Rede Lecture and Related Speeches and Articles (Cambridge University Press, 1998).

${ }^{7}$ Ivan T Berend, An economic history of twentieth-century Europe: Economic regimes from laissez-faire to globalization (Cambridge University Press, 2016).
} 
by means of governmental authority. With this pandemic, human movement across the globe has decreased, the number of international flights has been reduced, and many countries have closed their borders to the world. All these actions suggest that humanity's future will be different from what it used to be before the pandemic.

At this point a question arises whether Covid-19 will strengthen the tendency towards deglobalisation or not. Following the travel bans, restrictions in airlines, limitation of health products trade by governments, a decrease in physical mobility is observed. Yet, at the same time, the fact that people across the globe communicate with each other online at a higher level has created a higher level of interaction and sharing especially in the spheres of arts and sciences.

Although the advances achieved in preventing, controlling and treating contagious diseases increase our capability to react when faced with pandemics, human behaviour, demographic characteristics and globalisation processes related to mobility have increased the risk of a pandemic outbreak and accelerated global contagion. In recent years, globalisation has shaped the social and economic changes which accelerate the spread of new viruses ${ }^{8}$. While the increase in human movement accelerates the speed at which microbes travel, urbanisation has facilitated the spread of contagious diseases 9 . Despite this, globalisation has facilitated international cooperation and supported advancements in disease research and observation ${ }^{10}$.

Globalisation is considered to be instrumental in spreading pandemics. The increase in mobility in the globalising world causes diseases to spread much faster. In this context, in order to determine future policies, it is important to research whether globalisation will be instrumental in spreading Covid-19. During the Covid-19 pandemic period, the importance of technological innovations is understood for health protection ${ }^{11}$.

\section{Data and Method}

The number of cases confirmed as of April 1, 2020 was used as data in the present study $^{12}$. The KOF Index of Globalisation which is developed by Gygli, Savina, Florian Haelg, Niklas Potrafke and Jan-Egbert Sturm was used as the variable in regression analysis in order to investigate the effect of globalisation on the number of Covid-19 cases $^{13}$. The GeoDa software was used in the analysis of the data investigated in the study. The spatial weight matrix to be used in the study was formed in accordance with the threshold-distance model.

\footnotetext{
8 Patrick R Saunders-Hastings and Daniel Krewski, "Reviewing the history of pandemic influenza: understanding patterns of emergence and transmission," Pathogens 5, no. 4 (2016).

${ }^{9}$ Ronald Labonté, Katia Mohindra, and Ted Schrecker, "The growing impact of globalization for health and public health practice," Annual review of public health 32 (2011).

${ }^{10}$ Saunders-Hastings and Krewski, "Reviewing the history of pandemic influenza: understanding patterns of emergence and transmission."

${ }^{11}$ E Stawicka and A Parlinska, "12 Emerging Wireless Technologies Based on IoT in Healthcare Systems in Poland," in IoT Security Paradigms and Applications: Research and Practices, ed. Bharat Bhushan Sudhir Kumar Sharma, Narayan C. Debnath (CRC Press, 2020).

${ }^{12}$ CSSE, Johns Hopkins. "2019 Novel Coronavirus Covid-19 (2019-Ncov) Data." (2020).

${ }^{13}$ Savina Gygli et al., "The KOF Globalisation Index - revisited," The Review of International Organizations 14, no. 3 (2019/09/01 2019), https://doi.org/10.1007/s11558-019-09344-2, https://doi.org/10.1007/s11558-019$09344-2$.
} 
The model below was used in the study for regression analysis:

LNCovid19 $=\alpha_{0}+\beta_{1}$ Globalisation $+u_{1}$

For spatial autocorrelation, regions' spatial neighbourhood relations must be studied. Spatial autocorrelation compares two sets of information based on the similarity of observations and locations.

The structure of spatial autocorrelation is related to the locations of observations within the geographic space. Spatial autocorrelation test yields positive and negative autocorrelation. If observation values which are close to each other are similar, they as a whole show a positive spatial autocorrelation pattern; and if close observations have different values, they show a negative spatial autocorrelation pattern ${ }^{14}$.

Today there is an abundance of different methods to measure spatial autocorrelation. One of the commonly used methods is Moran's I developed by Patrick Moran. Moran's I is calculated in relation to the error terms of the ordinary least squares estimate ${ }^{15}$. Moran's I statistics can be assigned values between $(-1,1)$. When Moran's I test statistics is positive, a spatial autocorrelation exists between error terms and the closer the value is to 1 , the greater is the strength of positive spatial autocorrelation. When the test's result is negative, it is concluded that a negative spatial dependence exists ${ }^{16}{ }^{17}$. Spatial autocorrelation analysis include global (cluster test) and local (cluster test), Moran's I statistics tests and their visualisation ${ }^{18}$.

In this study, Moran's I was used for spatial autocorrelation. The formula for Moran's I test statistics is indicated below:

$$
I=\frac{\sum_{i} \sum w_{i j} z_{i} \cdot z_{j} / S_{0}}{\sum z^{2} / n}
$$

Here $z_{i}=x_{i}-\bar{x}$ ve $\bar{x} \mathrm{X} x$ indicates the mean of the variable.

To investigate whether countries are different from their neighbouring countries in terms of Covid-19 or not and whether this difference is significant, Local Moran's I Statistics was used. Local Indicator of Spatial Association (LISA) statistics was developed by Luc Anselin ${ }^{19}$. This statistic determines whether a significant spatial clustering or discrepancy exists; that is to say, it provides each region's comparative statistics with its neighbours. Moran's I statistics is formulised for each i region and t year as indicated below ${ }^{20}$ :

$$
\mathrm{I}_{\mathrm{i}}=\frac{\mathrm{z}_{\mathrm{i}}}{\mathrm{m}_{0}} \sum_{\mathrm{j}} \mathrm{W}_{\mathrm{ij}} \mathrm{Z}_{\mathrm{j}} \quad \text { with } \mathrm{m}_{0}=\sum_{\mathrm{i}} \mathrm{Z}_{\mathrm{i}}^{2} /_{\mathrm{N}}
$$

In the formula, the row-standardised form of weight matrix $W_{i j}$ is the element of $\mathrm{W}$ and $Z_{i}\left(Z_{j}\right)$ is the observation in the $\mathrm{i}(\mathrm{j})$ district.

\footnotetext{
${ }^{14}$ Manfred M Fischer and Jinfeng Wang, Spatial data analysis: models, methods and techniques (Springer Science \& Business Media, 2011).

${ }^{15}$ Metehan Yılgör, Mekansal Ekonometri: Mekansal Yatay Kesit ve Mekansal Panel Veri Modelleri (İstanbul: DER Yayınları, 2019).

${ }^{16}$ Fischer and Wang, Spatial data analysis: models, methods and techniques.

${ }^{17}$ Yllgör, Mekansal Ekonometri: Mekansal Yatay Kesit ve Mekansal Panel Veri Modelleri.

${ }^{18}$ Luc Anselin, Ibnu Syabri, and Youngihn Kho, "GeoDa: an introduction to spatial data analysis," in Handbook of applied spatial analysis (Springer, 2010).

${ }^{19}$ Luc Anselin, "Local indicators of spatial association-LISA," Geographical analysis 27, no. 2 (1995).

${ }^{20}$ Y1lgör, Mekansal Ekonometri: Mekansal Yatay Kesit ve Mekansal Panel Veri Modelleri.
} 
Spatial Error Model (SEM) is used in cases such as omitted variable, measurement error, and spatial heterogeneity. SEM is shown with two formulas ${ }^{21}$ :

$$
\begin{gathered}
y=x \beta+\varepsilon \\
\varepsilon=\lambda W \varepsilon+u
\end{gathered}
$$

Here $y$ shows the i dependent variable; $X$ the independent variable; $\mathrm{u}$ random error term; $\lambda$ the coefficient of the spatial error.

\section{Econometric Results}

Spatial distribution map of Covid-19 cases is given below in Figure 1. The darkest colour demonstrates the countries with the highest number of cases. Countries marked with less dark and light colours are observed to form a cluster as demonstrated in Figure 1. Taking this into account, it can be suggested that spatio-sequential dependence exists visually.

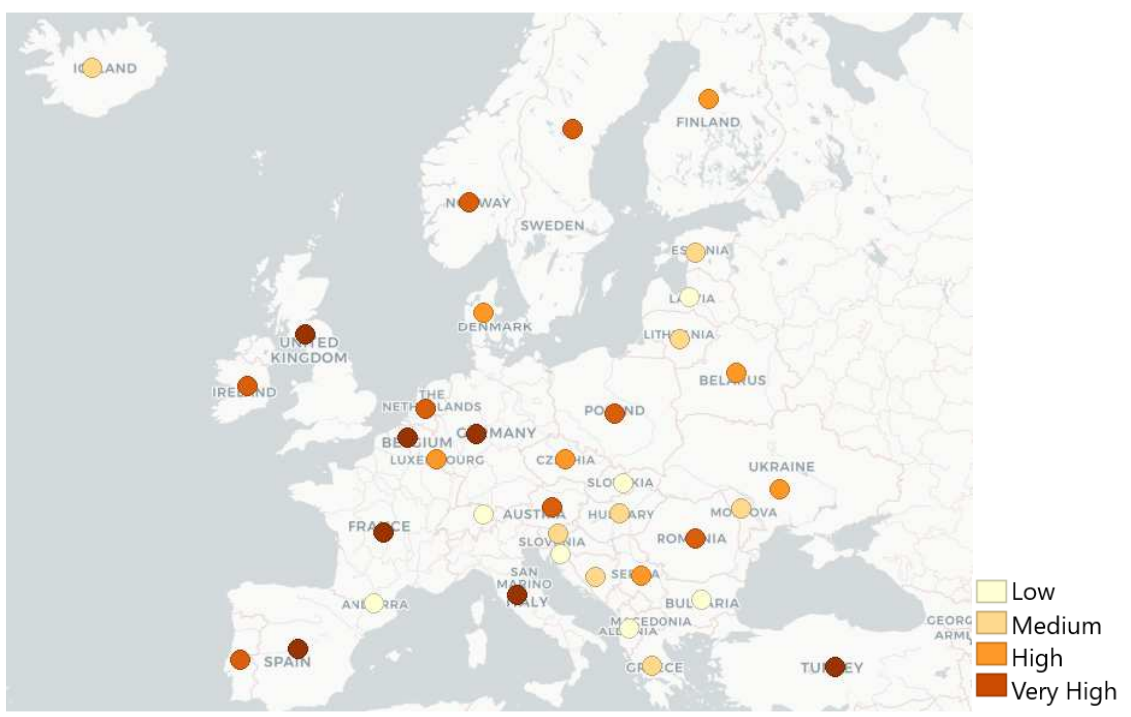

Figure 1. Spatial Distribution of Covid-19 Cases Data

Source: CSSE, Johns Hopkins. "2019 Novel Coronavirus Covid-19 (2019-Ncov) Data." (2020).

Having obtained visual information about spatial autocorrelation, we can test it with Moran's I statistics. The Moran's I test statistics of Covid-19 cases is given below.

${ }^{21}$ Fatma Zeren, Mekansal Ekonometri: GeoDa, GeoDaSpace ve R Uygulamalı (İstanbul: DER Yayınları, 2018). 


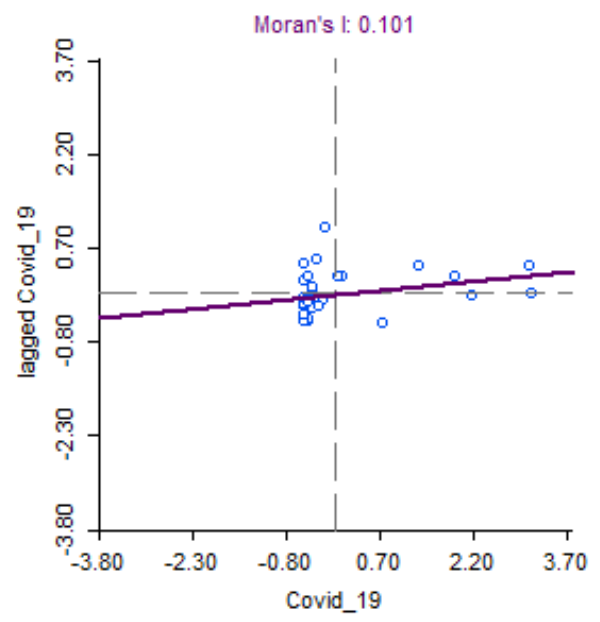

Figure 2. Moran Scatter Plot of Covid-19 Cases

Sources: Author's Own Estimation

Moran's I test statistics, which was calculated as 0.101 for Covid-19 cases, is statistically significant at $5 \%$ significance level and shows that there is positive autocorrelation.

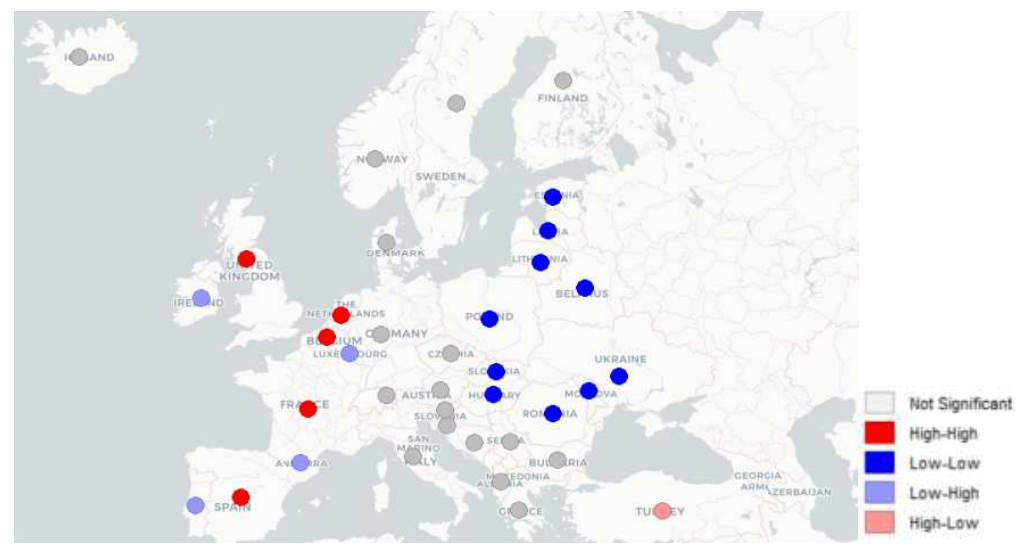

Figure 3. LISA Map of Covid-19 Cases

Source: CSSE, Johns Hopkins. "2019 Novel Coronavirus Covid-19 (2019-Ncov) Data." (2020).

In Figure 3, the $\mathrm{HH}$ region marked with the colour red in the LISA map of Covid19 cases includes Belgium, the Netherlands, the United Kingdom, France and Spain; these countries have a higher number of cases above the world average and are in relation with countries which have high number of cases. Having fewer cases than the world average but interacting with countries that have a high number of cases, the LH region includes Ireland, Andorra, Luxembourg, and Portugal. The HL region which has a higher number of cases than the world average and is in contact with regions that have 
lower numbers of cases includes only Turkey. Hungary, Moldova, Poland, Romania, Slovak Republic, Ukraine, Belarus, Latvia, Lithuania, and Estonia form the LL region which has a low number of cases.

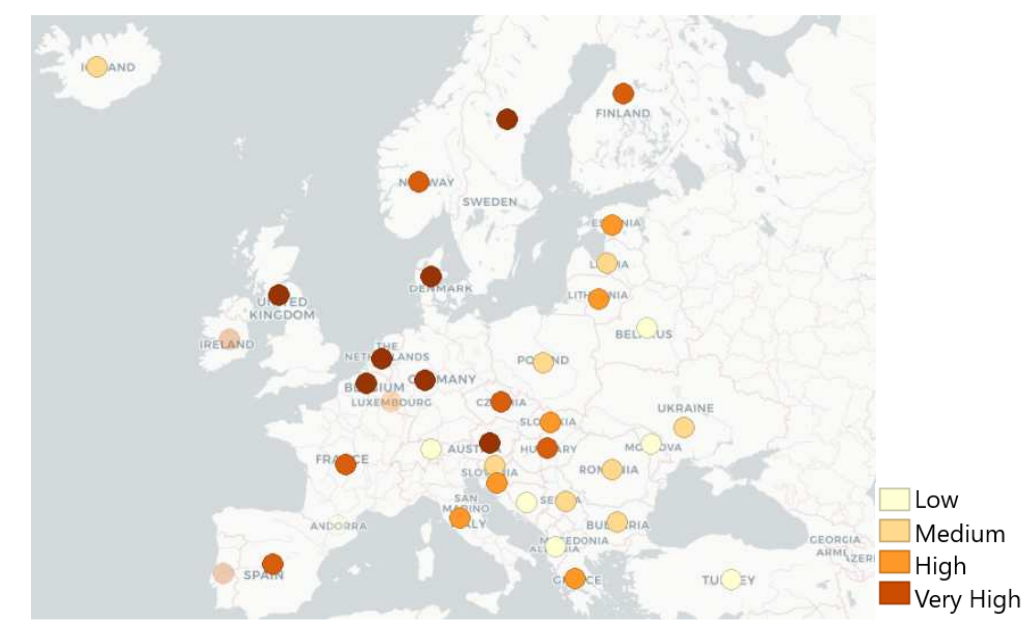

Figure 4. Spatial Distribution of Globalisation

Source: Gygli, Savina, Florian Haelg, Niklas Potrafke, and Jan-Egbert Sturm. "The Kof Globalisation Index Revisited." The Review of International Organizations 14, no. 3 (2019/09/01 2019): 543-74. https://doi.org/10.1007/s11558-019-09344-2.

When we categorise into 5 groups the European countries investigated; the first group includes Austria, Belgium, Denmark, Germany, the Netherlands, Sweden, and the United Kingdom. The rankings of these countries in the world globalisation index in 2019 follow respectively as: 6, 3, 8, 7, 2, 4, 7. As can be seen, the European countries rank in the top 10 in the world. The second group includes Czech Republic, Finland, France, Hungary, Ireland, Norway, Portugal, and Spain. The rankings of these countries in the 2019 world globalisation index follow respectively as: 13, 9, 10, 19, 17, 11, 15, 12. The third group includes Croatia, Estonia, Greece, Italy, Slovak Republic, Lithuania, and Luxembourg; the fourth group includes Bulgaria, Iceland, Poland, Romania, Slovenia, Ukraine, Latvia, and Serbia; the fifth group includes Albania, Bosnia and Herzegovina, Moldova, Turkey, Andorra, Belarus, and Liechtenstein.

Following the investigation of spatial clustering of Covid-19 cases in Europe, the effect of the countries' globalisation level on Covid-19 cases was investigated by using spatial analysis methods. In this context, the question whether globalisation is an effective factor on Covid-19 cases was attempted to be answered by determining spatial autocorrelation. In order to measure the effect of globalisation on the number of Covid19 cases, a regression model was formed. The model's parameters were estimated with ordinary least squares method (OLS). The estimations related to this model are indicated below in Table 1. 
Table 1. Spatial Autocorrelation and OLS Estimations

\begin{tabular}{|l|l|l|}
\hline Variable & Value & Prob. \\
\hline Constant & 3.42 & 0.12 \\
\hline Globalisation & 0.11 & 0.00 \\
\hline Moran's I & 0.13 & 0.00 \\
\hline$L M_{\text {lag }}$ & 2.81 & 0.09 \\
\hline$R L M_{\text {lag }}$ & 0.22 & 0.64 \\
\hline$L M_{\text {error }}$ & 3.73 & 0.05 \\
\hline$R L M_{\text {error }}$ & 1.15 & 0.28 \\
\hline Jarque-Bera & 2.20 & 0.33 \\
\hline Breusch-Pagan & 0.03 & 0.86 \\
\hline MCD: 16.72616 & Schwarz criterion: & 143.486 \\
\hline R-squared: 0.314558 & Akaike info criterion: & 140.264 \\
\hline
\end{tabular}

Sources: Author's Own Estimation

According to Moran's I statistics which investigates the presence of spatial autocorrelation, it is seen that spatial autocorrelation is present in the model. Both models are valid according to the LMlag and LMerror test results' $10 \%$ significance level. Therefore, it can be said that both Spatial Lag Model and Spatial Error Model are valid. However, at 5\% significance level, null hypothesis is rejected only in LMerror model. According to the OLS estimation results, the globalisation coefficient was found to be positive as expected. The results of the Spatial Error Model are given in Table 2.

Table 2. Estimation Results of Spatial Error Model

\begin{tabular}{|l|l|l|}
\hline Variable & Value & Prob. \\
\hline Constant & 3.6552 & 0.0732 \\
\hline Globalisation & 0.1062 & 0.0000 \\
\hline Lambda & 0.5749 & 0.0209 \\
\hline Breusch-Pagan & 0.0320 & 0.8581 \\
\hline R-squared: 0.385401 & Akaike criterion: 137.206 & Schwarz criterion: 140.427 \\
\hline
\end{tabular}

Sources: Author's Own Estimation

In this study, the main model used to investigate the effect of globalisation variable on Covid-19 cases is the Spatial Error Model. When Table 2, which shows the estimation results of the Spatial Error Model, is examined, the globalisation variable is seen to have a positive effect on the number of Covid-19 cases in the scope of Europe. The determination coefficient for the Spatial Error Model was found as 0.38. In this light, the relevant independent variable explains the dependent variable at a rate of 0.38. The AIC and SC values obtained from this model are lower than the AIC and SC values obtained from the OLS. The fact that these criteria have lower values shows that the Spatial Error Model gives better results than the conventional model. In addition, Lambda coefficient is statistically significant. 


\section{Conclusion}

In this study, the differences between the spatial patterns of Covid-19 in Europe on a country basis are presented. Additionally, the study attempted to determine the effect of globalisation on the number of Covid-19 cases. With the Moran's I value of the number of Covid-19 cases, a positive spatial autocorrelation was found, and the relation types were demonstrated by means of Moran Scatter Plot. Local spatial relations were investigated with LISA analysis. Following the analysis, a regression model was formed based on the notion that globalisation may increase the spread of pandemics. According to the results of the spatial dependence tests, the spatial error model was found to be valid and the study was furthered with the estimation of the spatial error model. Having examined the AIC and SC information criteria, it was found that the spatial error model gave more significant results than the conventional regression model. In light of the results of the spatial error model, it was found that globalisation had a positive effect on the number of Covid-19 cases in Europe.

In the post Covid-19 era, different globalisation regulations and structures are expected to develop in economic, political, and social areas. It is remarked that the concept of 'normal' will no longer have the same meaning as before the Covid-19 pandemic. In this context, it is not possible to evaluate economic life through the old concept of normality. The fact that globalisation is found to have a positive impact on Covid-19 cases in European countries indicates the need for new regulations concerning globalisation in economic and social areas. The product and service-related commercial problems in healthcare that Europe and the world faced are considered to have an effective role in causing the pandemic to spread at such a great pace. The reaction against restrictive measures was strong in European countries where political freedom is comparatively higher. The failure to have urgent access essential protections such as face masks and disinfectants has called for a questioning of external dependence in certain production areas. The external dependence in terms of countries' food safety has come to be questioned as well.

Many studies engage with the future of globalisation after the Covid-19 pandemic. However, globalisation's contribution to the condition we are going through must be taken into consideration while carrying out studies/research about how globalisation should evolve. Determining in which areas globalisation has been effective on the spread of the pandemic with in-depth analyses is a factor that must be taken into consideration in terms of shaping the future of globalisation. The findings of the study have shown that globalisation has proved to be effective not only in spreading economic crises across the globe, but also in spreading pandemics in a similar fashion.

\section{References}

Anselin, Luc. "Local Indicators of Spatial Association-Lisa." Geographical analysis 27, no. 2 (1995): 93-115.

Anselin, Luc, Ibnu Syabri, and Youngihn Kho. "Geoda: An Introduction to Spatial Data Analysis." In Handbook of Applied Spatial Analysis, 73-89: Springer, 2010.

Baldwin, Richard, and Beatrice Weeder di Maura. Economics in the Time of Covid-19. CEPR Press, 2020. 
Berend, Ivan T. An Economic History of Twentieth-Century Europe: Economic Regimes from Laissez-Faire to Globalization. Cambridge University Press, 2016.

Brittan, Leon. Globalisation Vs. Sovereignty? The European Response: The 1997 Rede Lecture and Related Speeches and Articles. Cambridge University Press, 1998.

CSSE, Johns Hopkins. "2019 Novel Coronavirus Covid-19 (2019-Ncov) Data." (2020). https://github.com/CSSEGISandData/COVID-19.

del Rio-Chanona, R Maria, Penny Mealy, Anton Pichler, Francois Lafond, and Doyne Farmer. "Supply and Demand Shocks in the Covid-19 Pandemic: An Industry and Occupation Perspective." arXiv preprint arXiv:2004.06759 (2020).

"Novel Coronavirus (Covid-19)." 2020, http://www.fao.org/2019-ncov/q-and-a/impact-on-foodand-agriculture/en/.

Fischer, Manfred M, and Jinfeng Wang. Spatial Data Analysis: Models, Methods and Techniques. Springer Science \& Business Media, 2011.

Gygli, Savina, Florian Haelg, Niklas Potrafke, and Jan-Egbert Sturm. "The Kof Globalisation Index - Revisited." The Review of International Organizations 14, no. 3 (2019/09/01 2019): 54374. https://doi.org/10.1007/s11558-019-09344-2. https://doi.org/10.1007/s11558-019-09344-2.

Labonté, Ronald, Katia Mohindra, and Ted Schrecker. "The Growing Impact of Globalization for Health and Public Health Practice." Annual review of public health 32 (2011).

Novel, Coronavirus Pneumonia Emergency Response Epidemiology. "The Epidemiological Characteristics of an Outbreak of 2019 Novel Coronavirus Diseases (Covid-19) in China." Zhonghua liu xing bing xue za zhi= Zhonghua liuxingbingxue zazhi 41, no. 2 (2020): 145.

Saunders-Hastings, Patrick R, and Daniel Krewski. "Reviewing the History of Pandemic Influenza: Understanding Patterns of Emergence and Transmission." Pathogens 5, no. 4 (2016): 66.

Stawicka, E, and A Parlinska. "12 Emerging Wireless Technologies Based on Iot in Healthcare Systems in Poland." In Iot Security Paradigms and Applications: Research and Practices, edited by Bharat Bhushan Sudhir Kumar Sharma, Narayan C. Debnath, 261: CRC Press, 2020.

Yllgör, Metehan. Mekansal Ekonometri: Mekansal Yatay Kesit Ve Mekansal Panel Veri Modelleri. İstanbul: DER Yayınları, 2019.

Zeren, Fatma. Mekansal Ekonometri: Geoda, Geodaspace Ve $R$ Uygulamalı. İstanbul: DER Yayınları, 2018.

\section{Analiza przestrzenna relacji między przypadkami Covid-19 a globalizacją w Europie}

\section{Streszczenie}

Wraz z procesem globalizacji struktury gospodarcze, społeczne i polityczne stają się coraz bardziej ze sobą powiązane. Ze względu na obecną pandemię Covid-19 zaobserwowano, że epidemie takie jak Covid-19 zglobalizują się i przekształcają się w pandemie na skalę globalną. W badaniu tym sugeruje się, że wraz z charakterystycznymi zdolnościami Covid-19, takimi jak szybkie rozprzestrzenianie się, fakt, że świat stał się bardziej mobilny i zintegrowany z powodu globalizacji, jest uważany za mający wpływ na pandemię; w związku z tym wpływ globalizacji na przypadki Covid-19 w krajach europejskich badano za pomocą metod analizy przestrzennej. Wyniki testu I Morana przeprowadzonego na temat przypadków Covid-19 w krajach europejskich sugerują, że istnieje pozytywna autokorelacja Zgodnie z wynikami analizy LISA stwierdzono, że Zjednoczone Królestwo, Niderlandy, Francja i Belgia mają nie tylko większą liczbę spraw dotyczących covid-19, ale także zostały dotknięte przez kraje, w których wiele przypadków jest powyżej średniej europejskiej. Zgodnie z wynikami modelu błędu przestrzennego mającego na 
celu zbadanie wpływu globalizacji stwierdzono, że globalizacja miała niewielki, ale pozytywny wpływ na przypadki Covid-19 w Europie.

Słowa kluczowe: analizy przestrzenne, Covid-19, Europa, globalizacja

JEL codes: I1, P1, F6

Information about author:

Dr Yılmaz Toktaş

Amasya University, Turkey

Department of Economics,

Faculty of Economics and Administrative Sciences,

e-mial: toktasyilmaz@gmail.com,

ORCID: 0000-0002-6996-7987 